\title{
Correction to: Improvements in cholesterol efux capacity of HDL and adiponectin contribute to mitigation in cardiovascular disease risk after bariatric surgery in a cohort with morbid obesity
}

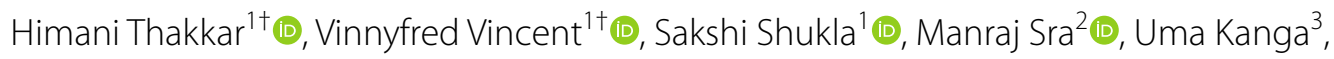

Sandeep Aggarwal ${ }^{4}$ and Archna Singh ${ }^{1 *}$ (1)

\section{Correction to: Diabetol Metab Syndr (2021) 13:46} https://doi.org/10.1186/s13098-021-00662-3

It was highlighted that the original article [1] contained an error in the family name of author Sakshi Shukla. It was incorrectly captured as Sakshi Sukhla. The original article has been updated. bariatric surgery in a cohort with morbid obesity. Diabetol Metab Syndr. 2021;13:46. https://doi.org/10.1186/s13098-021-00662-3.

\section{Publisher's Note}

Springer Nature remains neutral with regard to jurisdictional claims in published maps and institutional affiliations.

\begin{abstract}
Author details
'Department of Biochemistry, All India Institute of Medical Sciences, Room No. 3044, New Delhi 110029, India. ${ }^{2}$ All India Institute of Medical Sciences, New Delhi, India. ${ }^{3}$ Department of Transplant Immunology and Immunogenetics, All India Institute of Medical Sciences, New Delhi, India. ${ }^{4}$ Department of Surgical Disciplines, All India Institute of Medical Sciences, New Delhi, India.
\end{abstract}

Published online: 14 June 2021

\section{Reference}

1. Thakkar, et al. Improvements in cholesterol efux capacity of HDL and adiponectin contribute to mitigation in cardiovascular disease risk after
The original article can be found online at https://doi.org/10.1186/s13098021-00662-3.

\footnotetext{
*Correspondence: arch_singh@ymail.com
}

†Himani Thakkar and Vinnyfred Vincent contributed equally to this work

1 Department of Biochemistry, All India Institute of Medical Sciences, Room No. 3044, New Delhi 110029, India

Full list of author information is available at the end of the article

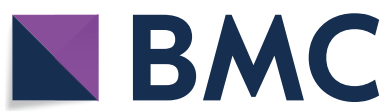

(0) The Author(s) 2021. This article is licensed under a Creative Commons Attribution 4.0 International License, which permits use, sharing, adaptation, distribution and reproduction in any medium or format, as long as you give appropriate credit to the original author(s) and the source, provide a link to the Creative Commons licence, and indicate if changes were made. The images or other third party material in this article are included in the article's Creative Commons licence, unless indicated otherwise in a credit line to the material. If material is not included in the article's Creative Commons licence and your intended use is not permitted by statutory regulation or exceeds the permitted use, you will need to obtain permission directly from the copyright holder. To view a copy of this licence, visit http://creativecommons.org/licenses/by/4.0/. The Creative Commons Public Domain Dedication waiver (http://creativecommons.org/publicdomain/zero/1.0/) applies to the data made available in this article, unless otherwise stated in a credit line to the data. 